\title{
Assessment of genetic variation in Linum L. using SPAR markers
}

\author{
Zahra Noormohammadi ${ }^{*}$, \\ Mina Sakhaee ${ }^{1}$, \\ Masoud Sheidai², \\ Seyed Mehdi Talebi \\ ${ }^{1}$ Department of Biology, \\ Science and Research Branch, \\ Islamic Azad University, Tehran, Iran \\ ${ }^{2}$ Faculty of Biological Sciences, \\ Shahid Beheshti University, Tehran, Iran \\ ${ }^{3}$ Department of Biology, \\ Faculty of Sciences, \\ Arak University, Arak
}

\begin{abstract}
Flax (Linum usitatissimum subsp. usitatissimum) is an important crop plant cultivated both for its fiber and seed oil content. Uniform cultivation and selection practice may lead to genetic erosion and reduced genetic variability of Linum cultivars, which in turn makes the crop vulnerable to diseases and pathogens. Therefore we performed a genetic diversity analysis of few populations including both Linum usitatissimum subsp. usitatissimum L. and L. Bienne L. We used a combination of single primer amplification reaction markers, including RAPD, ISSR, and RAMPO molecular markers for genetic variability study. In general, all three molecular markers revealed a low degree of genetic variability in the materials studied; however, $L$. bienne had a higher level of genetic variability. Clustering and network analyses grouped the studied plants inter-mixed and did not separate the studied species or populations. STRUCTURE plot and K-Means clustering also identified these populations as genetically homogenous. These results indicate the need for introducing new linseed cultivars into the country for future hybridization and breeding programmes.
\end{abstract}

Keywords: genetic variability, K-Means clustering, Linum, STRUCTURE analysis, SPAR

\section{INTRODUCTION}

Flax (Linum usitatissimum subsp. usitatissimum) is a diploid, annual plant species. Since flax, and in particular fiber flax, has been such an important cultivated crop, it is a matter of great importance to conserve the genetic material of flax as widely as possible for future utilization in breeding. Presently, the largest producers of fiber flax are China, Russia, Belarus, and Ukraine, while oilseed production is important in India, Canada, China,

\footnotetext{
* Corresponding author. E-mail: marjannm@yahoo.com, z-nouri@srbiau.ac.ir
}

United States, Germany, Argentina, United Kingdom, and Spain (Žiarovská et al., 2012).

Linum appears to have arisen in Eurasia, from which it spread to Africa, North America, South America, and Australasia (McDill et al., 2009).

The cultivation of wild flax dates back to around 9,000 B.C.E., as evidenced by the oldest archaeological flax seeds from excavation sites in Syria. Linum bienne Mill. (= L. angustifolium Huds.) is perhaps the oldest flax wild form cultivated. Its cultivation for fiber and seeds is believed to have led to the development of L. usitatissimum L., the modern cultivated flax, one of the early domesticated plants (McDill et al., 2009). 
Divergent selection applied over thousands of years has resulted in fiber and linseed types of Linum which are the same species but differ considerably in morphology, anatomy, physiology, and agronomic performance (Soto-Cerda et al., 2013).

Linum species, such as the red-flowered L. grandiflorum Desf., the blue-flowered L. Perenne L., and the yellow-flowered L. Flavum L., are also of ornamental value. In recent years, lignansand $\alpha$-linolenic acids of Linum have been explored for their usefulness in the treatment of cardiovascular diseases and cancer, particularly breast cancer (Sheidai et al., 2014). These medicinal applications have stimulated renewed interest in the studies related to the genetic and systematic relationships among Linum species.

Genetic diversity analysis is an important task in plant breeding as diversity in plant genetic resources (PGR) provides an opportunity for plant breeders to develop new and improved cultivars with desirable characteristics (Govindaraj et al., 2015). Genetic diversity helps organisms cope with current environmental variability (Freeland et al., 2011). Genetic diversity also reduces the incidence of unfavourable inherited traits due to inbreeding and produces a diverse array of genotypes that can resist diseases and pathogens (Freeland et al., 2011).

Population genetic studies can picture genetic variability of the species, the gene flow, inbreeding versus outbreeding, effective population size, and population bottleneck. These data are helpful in choosing effective management in conservative strategies, shed light on the current infra-specific taxonomic forms, and suggest a proper hybridization plan (Sheidai et al., 2014). Therefore, we performed a population genetic study of three available populations in either of Linum usitatissimum L. (cultivated flax) and Linum austriacum L. to provide data on the genetic structure and genetic variability in these species.

Recently, interesting studies have been performed in our country on population genetic structure of Linum species, both cultivated and wild (see, for example, Sheidai et al., 2014; Afshar et al., 2015; Habibollahi et al., 2016 a, b).
These authors used SSR (simple sequence repeats), EST-SSR (expressed sequence tags), ISSR (inter-simple sequence repeats) molecular markers and reported a low degree of genetic variability in the studied species. The single primer amplification region (SPAR) markers such as RAMPO RAPD and ISSR have been used in genetic variation studies. RAMPO (random amplified microsatellite polymorphism) molecular markers are efficient discrimination markers that have been recently used in crop genetic variability assessment studies (see for example, Chatti et al., 2008; Tamarzizt et al., 2015). In RAMPO, two types of primers are in use. Initially, DNA amplification was conducted using universal decamer oligonucleotides (RAPDs), followed by using primers that are complementary to simple sequence repeats used to perform RAMPO assays. Finally, this method consists of the combination of these two PCR steps (Tamarzizt et al., 2015).

\section{MATERIALS AND METHODS}

\section{Plant materials}

In the present study, 40 plants were collected from four geographical populations of Iran. Three populations of Linum usitatissimum $\mathrm{L}$. (1 = Uromieh (West-Azarbayejan), $2=$ Shiraz (Fars), and 3 = Saveh (Markazi), respectively), and one population of Linum bienne L. were studied.

\section{DNA extraction and molecular markers assay}

Fresh leaves were used randomly from 5-10 plants in each of the studied populations. CTAB-activated charcoal protocol was used to extract genomic DNA based on Krizman et al. (2006) protocol. Nine RAPD and 7 ISSR as well as 10 RAMPO loci were used (Table 1). PCR reactions were carried out in a $25 \mu \mathrm{l}$ volume containing $10 \mathrm{mM}$ Tris- $\mathrm{HCl}$ buffer at $\mathrm{pH} 8 ; 50 \mathrm{mM}$ $\mathrm{KCl} ; 1.5 \mathrm{mM} \mathrm{MgCl} 2 ; 0.2 \mathrm{mM}$ of each dNTP (Bioron, Germany); $0.2 \mu \mathrm{M}$ of a single primer (used 2 primers used for RAMPO-PCR); 20 ng genomic DNA and $1 \mathrm{U}$ of Taq DNA polymerase (Bioron, Germany). The amplification reactions were performed in Techne thermocycler 
Table 1. RAPD, ISSR and RAMPO loci with their sequences

\begin{tabular}{|c|c|c|}
\hline RAPD loci & Sequence & RAMPO loci \\
\hline OPA02 & TGCCGAGCTG & $\begin{array}{c}\text { UBC } \\
807 / \text { OPA03 } \\
\end{array}$ \\
\hline OPA03 & AGTCAGCCAC & $\begin{array}{c}\text { UBC } \\
810 / \mathrm{OPA} 03\end{array}$ \\
\hline OPA04 & AATCGGGCTG & $\begin{array}{c}\text { UBC } \\
811 / \text { OPA03 }\end{array}$ \\
\hline OPA05 & AGGGGTCTTG & $\begin{array}{c}\text { UBC } \\
811 / \text { OPA09 }\end{array}$ \\
\hline OPA09 & GGGTAACGCC & $\begin{array}{c}\text { UBC } \\
810 / \text { OPA10 }\end{array}$ \\
\hline OPA10 & GTGATCGCAG & $\begin{array}{c}\text { UBC } \\
810 / \text { OPA04 }\end{array}$ \\
\hline ISSR loci & & $\begin{array}{c}\text { UBC } \\
811 / \text { OPA04 }\end{array}$ \\
\hline UBC807 & $(\mathrm{GA}) 8 \mathrm{~T}$ & $\begin{array}{c}\text { UBC } \\
811 / \text { OPA05 }\end{array}$ \\
\hline UBC810 & $(\mathrm{GA}) 8 \mathrm{~T}$ & $\begin{array}{c}\text { UBC } \\
811 / \text { OPA05 } \\
\end{array}$ \\
\hline UBC811 & $(\mathrm{GA}) 8 \mathrm{C}$ & $\begin{array}{c}\text { UBC } \\
807 \mathrm{OPA} 02\end{array}$ \\
\hline UBC834 & $(\mathrm{AG}) 8 \mathrm{YT}$ & \\
\hline UBC849 & (GT)8YA & \\
\hline$(\mathrm{CA})_{7} \mathrm{AC}$ & - & \\
\hline$(\mathrm{GA})_{9} \mathrm{~A}$ & - & \\
\hline$(\mathrm{GA})_{9} \mathrm{~T}$ & - & \\
\hline$(\mathrm{GA})_{9} \mathrm{C}$ & - & \\
\hline
\end{tabular}

(Germany) with the following program: $5 \mathrm{~min}$ initial denaturation step $94^{\circ} \mathrm{C}$, followed by 40 cycles of $30 \mathrm{~s}$ at $94^{\circ} \mathrm{C} ; 1 \mathrm{~min}$ at 37,50 and $38^{\circ} \mathrm{C}$ for RAPD, ISSR and RAMPO respectively and 2 min at $72{ }^{\circ} \mathrm{C}$. The reaction was completed by final extension step of $5 \mathrm{~min}$ at $72{ }^{\circ} \mathrm{C}$. The amplification products were observed by running on $1 \%$ agarose gel, followed by GelRed ${ }^{\text {Tw }}$ Nucleic Acid Gel Staining. The fragment size was estimated by using a $100 \mathrm{bp}$ molecular size ladder (Fermentas, Germany).

\section{Data analyses}

RAPD, ISSR and RAMPO bands obtained were coded as binary characters (presence $=1$, absence $=0$ ) and used for genetic diversity analysis. Parameter like Nei's gene diversity $(\mathrm{H})$, Shannon information index (I), number of effective alleles, and percentage of polymorphism were determined (Weising, 2005; Freeland et al., 2011).

Nei's genetic distance among populations was used for Neighbor Joining (NJ) clustering and networking (Freeland et al., 2011; Huson, Bryant, 2006). These analyses were done by PAST v2.17 (Hamer et al., 2012), DARwin v5 (2012) and SplitsTree4 v4.13.1 (2013) software.

AMOVA (Analysis of molecular variance) test (with 1000 permutations) as implemented in GenAlex 6.4 (Peakall, Smouse, 2006), and Nei's Gst analysis as implemented in GenoDive v2 (2013) (Meirmans, Van Tienderen, 2004) were used to show the genetic difference of the populations. Moreover, genetic differentiation of populations was studied by G'ST est $=$ standardized measure of genetic differentiation (Hedrick, 2005), and D_est = Jost measure of differentiation (Jost, 2008).

The genetic structure of the populations was studied by Bayesian-based model STRUCTURE analysis (Pritchard et al., 2000), and maximum likelihood-based method of K-Means clustering of GenoDive v2 (2013). For STRUCTURE analysis, data were scored as dominant markers (Falush et al., 2007). In K-Means clustering, two summary statistics, pseudo-F and Bayesian Information Criterion (BIC), provide the best fit for $k$ (Meirmans, 2012).

\section{RESULTS}

\section{Genetic diversity of the populations}

Genetic diversity parameters determined in the studied populations for all three molecular markers are presented in Table 2. In RAPD markers, population No. 4 (L. bienne) showed the highest degree of genetic polymorphism (30.94\%), while population No. 1 (Uromieh) of Linum usitatissimum L. showed the lowest degree of genetic diversity (26.93\%).

Abbreviations: $\mathrm{Na}=$ Mean number of alleles, $\mathrm{Ne}=$ Number of effective alleles, $\mathrm{I}=$ Shannon Information Index, $\mathrm{He}=$ Gene diversity, 
Table 2. Genetic diversity parameters in Linum usitatissimum, and L. bienne

\begin{tabular}{cc|c|c|c|c}
\hline $\begin{array}{c}\text { Popula- } \\
\text { tion }\end{array}$ & Na & Ne & I & He & P\% \\
\hline RAPD & & & & & \\
\hline Pop1 & 0.539 & 1.039 & 0.064 & 0.033 & 26.93 \\
\hline Pop2 & 0.580 & 1.040 & 0.067 & 0.034 & 29.02 \\
\hline Pop3 & 0.577 & 1.037 & 0.064 & 0.032 & 28.87 \\
\hline Pop4 & 0.619 & 1.045 & 0.074 & 0.038 & 30.94 \\
\hline ISSR & & & & & \\
\hline Pop1 & 0.590 & 1.046 & 0.074 & 0.039 & 29.50 \\
\hline Pop2 & 0.581 & 1.046 & 0.073 & 0.038 & 29.05 \\
\hline Pop3 & 0.529 & 1.036 & 0.061 & 0.031 & 26.48 \\
\hline Pop4 & 0.919 & 1.066 & 0.109 & 0.056 & 45.95 \\
\hline RAMPO & & & & & \\
\hline Pop1 & 0.942 & 1.065 & 0.110 & 0.056 & 47.00 \\
\hline Pop2 & 0.734 & 1.052 & 0.086 & 0.044 & 36.68 \\
\hline Pop3 & 0.479 & 1.052 & 0.076 & 0.042 & 23.95 \\
\hline & & & & &
\end{tabular}

and $\mathrm{P} \%=$ polymorphism. (Populations $1-4$ are: Urmia,Shiraz,Saveh (Linum usitatissimum), and Linum bienne).

In ISSRs, population No. 4 (L. bienne) had a low degree of genetic polymorphism (45.95\%), while population No. 3 (Saveh) of Linum usi- tatissimum L. showed the lowest degree of genetic diversity (26.93\%).

In the case of RAMPOs, we could not get a result for L. bienne, therefore a comparison was made between Linum usitatissimum populations. Population No. 1 (Uromieh) showed the highest genetic diversity (47.00\%, Table 2 ).

\section{Population genetic differentiation}

AMOVA and Gst analysis revealed a significant difference among the studied populations for all three molecular markers examined. For example in RAPDs, AMOVA produced Phi$\mathrm{PT}=0.04, P=0.01$.

AMOVA also revealed that $96 \%$ of total genetic variability was due to diversity within a population and only $4 \%$ was due to genetic differentiation among populations. These results indicated the presence of almost a homogenous genetic group.

\section{Genetic affinity of the populations}

Since the NJ tree and Net network analyses produced similar results for RAPDs and ISSRs, only ISSR Network is presented and discussed (Fig. 1). In both molecular markers we obtained a mixture of genotypes and no single population was

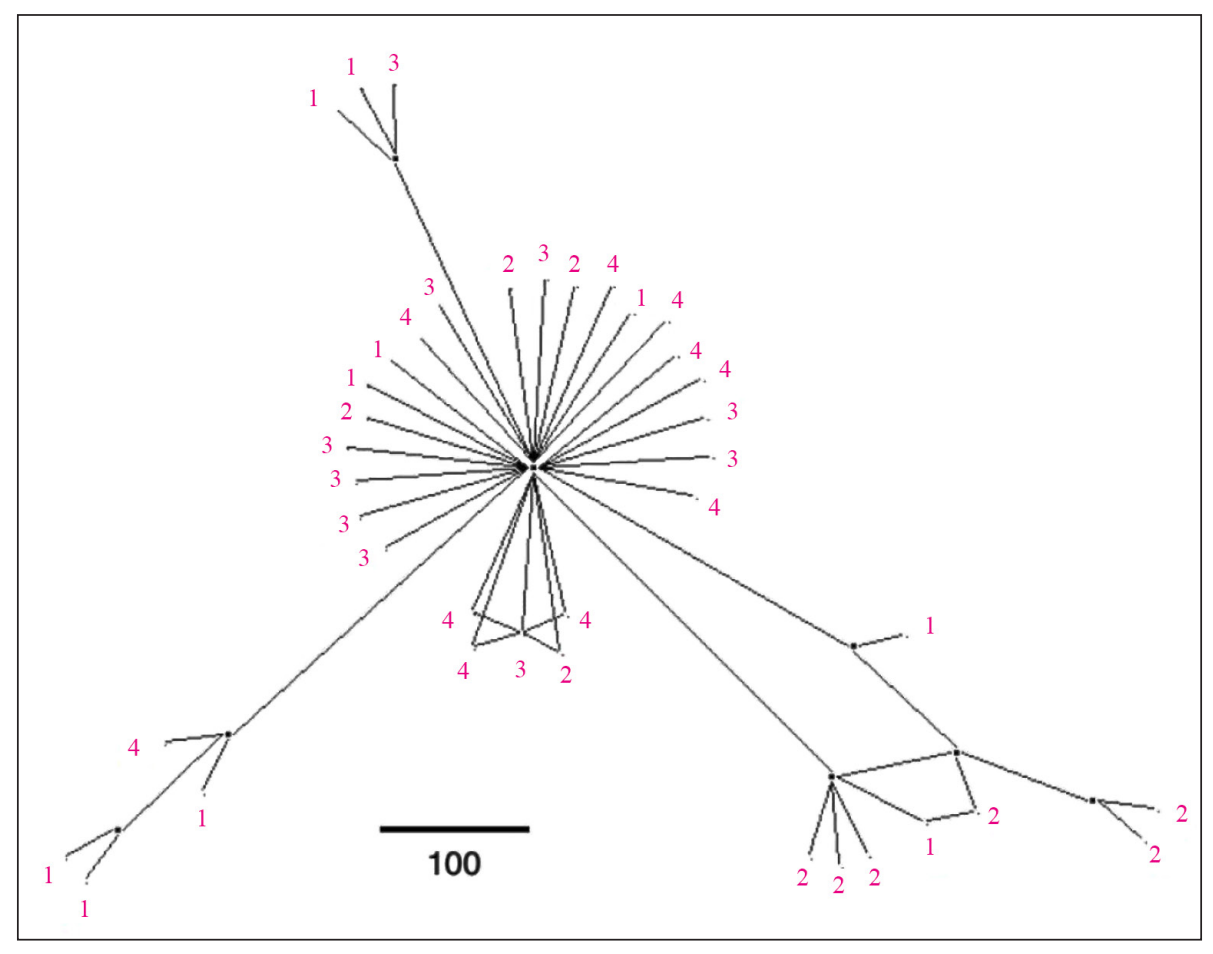

Fig. 1. Median-Joining network of ISSR data in L. usitatissimum and Linum bienne populations 
separated from the others. The samples of both Linum species were placed inter-mixed. This means that the two species are closely related and are not very divergent in parts of their genome that are revealed by RAPD and ISSR molecular markers.

In case of RAMPOs, in which only the populations of L. usitatissimum were studied, the mixture of samples from all three populations occurred again (Fig. 2).

\section{Population genetic structure}

$\mathrm{K}-$ Means clustering produced $\mathrm{k}=2$ according to pseudo-F and $\mathrm{k}=1$ according to BIC. Therefore, we have one or two distinct genetic groups. Similar result was obtained by STRUCTURE analysis (Fig. 3).

For example, the STRUCTURE plot of ISSR data revealed very similar genetic content in both studied species (similarly coloured segments). The only difference was the proportion

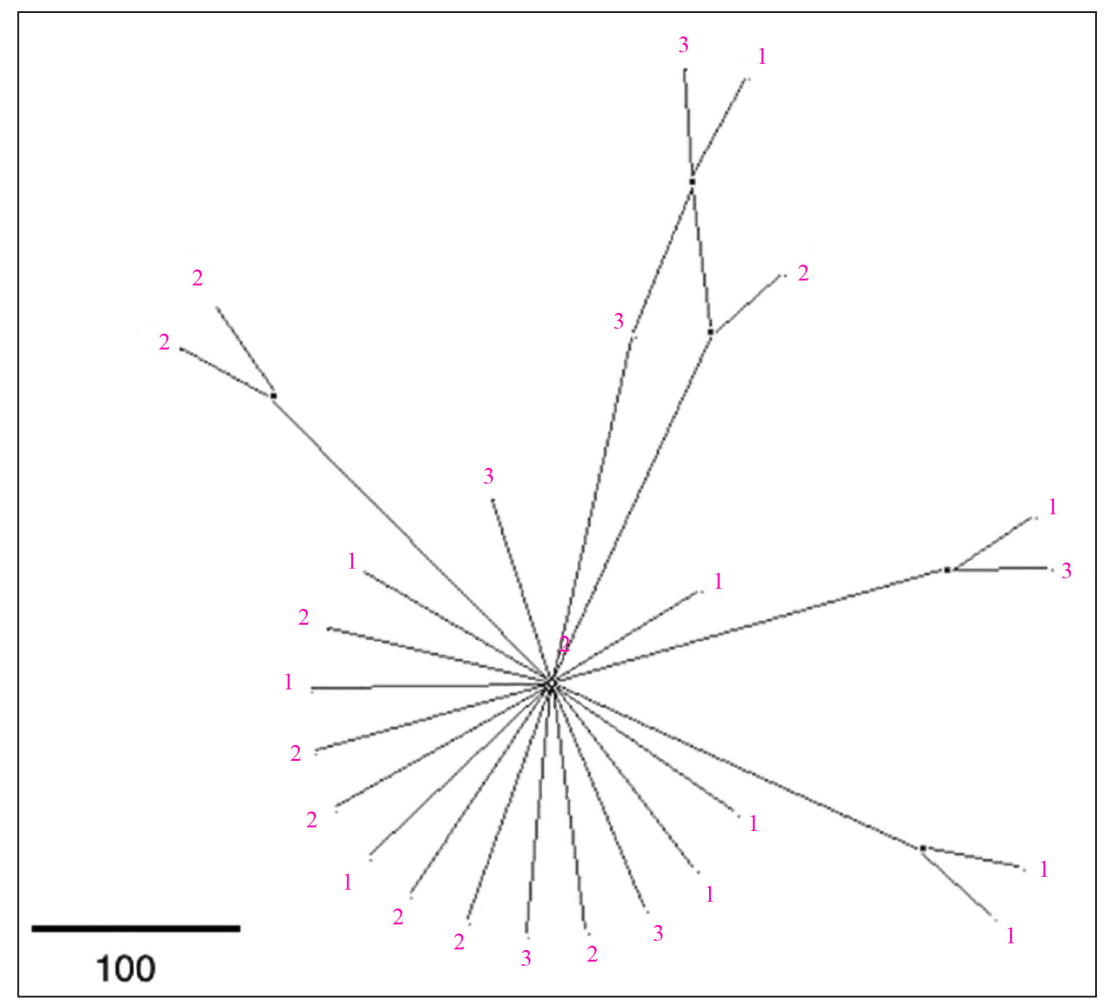

Fig. 2. Median-Joining network of RAMPO data in L. usitatissimum popuations

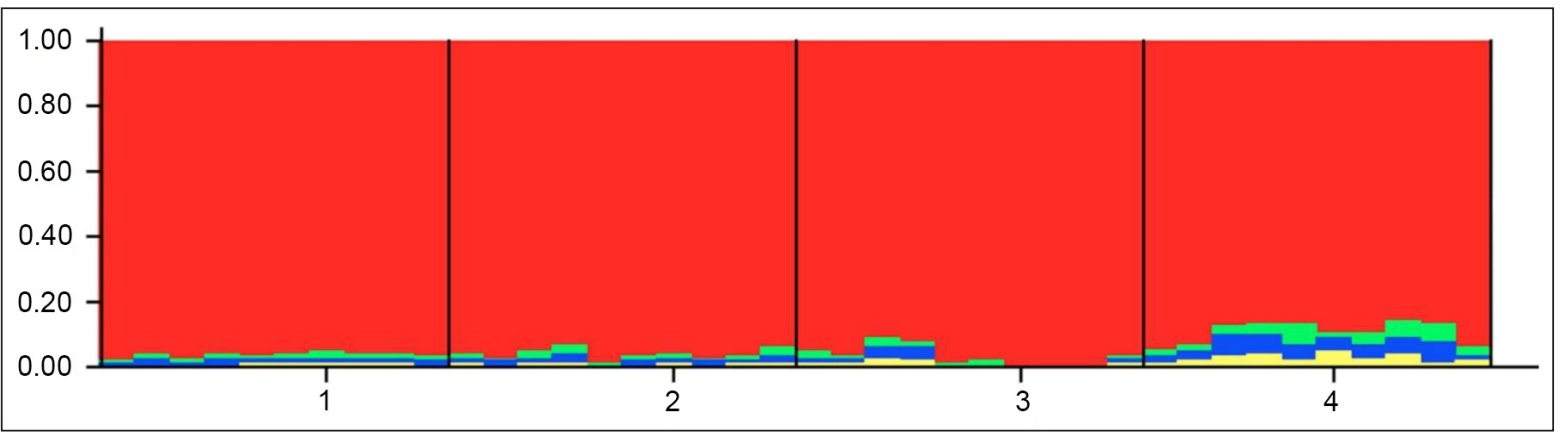

Fig. 3. STRUCTURE plot of ISSR data in L. usitatissimum (populations 1-3) and Linum bienne (population 4) populations 
of differently coloured segments in these populations. In this regard Linum bienne differed from L. usitatissimum populations. This high degree of genetic similarity between the two species and also among different populations in L. usitatissimum indicated either the presence of ancestral shared alleles or an ongoing gene flow among these populations.

Based on the likelihood method, the population assignment test performed on the studied species is presented in Table 3. Based on the ratio of likelihoods, 16 out of 40 plants were inferred to be from another population and were genetically more similar to them. For example, plants No. 5. 8, 9, and 10 of population 1 were inferred to be from populations 2 and 3. (Mostly they were genetically similar to population 2). Similarly, population 2 had some plants that were inferred to be from population 1. The same holds true for populations 3 and 1 , as well as populations 4 and 1 . These results are in agreement with STRUC-
TURE analysis in showing a high degree of genetic admixture among the studied species and populations.

Abbreviations: Lik_max = Maximum likelihood, Lik_home $=$ Home likelihood, and Lik_ ratio $=$ Ratio of Home likelihood/ Maximum likelihood.

\section{DISCUSSION}

Determination of genetic variability both within and among populations is one of the major findings in population genetic analysis. Genetic diversity is of fundamental importance in the continuity of a species as it provides the necessary adaptation to the prevailing biotic and abiotic environmental conditions, and changes in the genetic composition may help to overcome the environmental changes (Sheidai et al., 2014). In general we found a low degree of genetic diversity in the studied Linum species and populations.

Table 3. Population assignment test based on ISSR and RAPD among the studied populations (Only individuals that are inter-mixed are shown)

\begin{tabular}{ccccccc}
\hline Individual & Current & Inferred & Lik_max & Lik_home & Lik_ratio \\
\hline 5 & Pop001 & Pop003 & -36.015 & -42.928 & 13.826 \\
\hline 8 & Pop001 & Pop002 & -31.021 & -49.208 & 36.374 \\
\hline 9 & Pop001 & Pop002 & -45.432 & -48.109 & 5.353 \\
\hline 10 & Pop001 & Pop002 & -32.597 & -42.928 & 20.663 \\
\hline 14 & Pop002 & Pop001 & -54.714 & -64.842 & 20.257 \\
\hline 18 & Pop002 & Pop001 & -25.239 & -28.067 & 5.657 \\
\hline 23 & Pop002 & Pop001 & -58.709 & -60.439 & 3.462 \\
\hline 24 & Pop003 & Pop001 & -85.175 & -86.646 & 2.942 \\
\hline 25 & Pop003 & Pop004 & -83.055 & -83.602 & 1.094 \\
\hline 28 & Pop003 & Pop001 & -18.611 & -24.67 & 12.118 \\
\hline 29 & Pop003 & Pop001 & -15.603 & -19.489 & 7.773 \\
\hline 31 & Pop003 & Pop002 & -17.58 & -19.489 & 3.819 \\
\hline 37 & Pop004 & Pop001 & -58.76 & -59.146 & 0.771 \\
\hline 38 & Pop004 & Pop001 & -101.594 & -102.787 & 2.387 \\
\hline 40 & Pop004 & Pop001 & -124.425 & -126.303 & 3.754 \\
\hline & Pop004 & Pop003 & -61.671 & -74.541 & 25.74 \\
\hline
\end{tabular}


STRUCTURE plot and genetic diversity analysis revealed lesser genetic variability among cultivated flax and a higher degree of genetic variability within its wild relatives that is in agreement with other studies using SSR, EST-SSR, ISSR, and retrotransposon-based markers (IRAP) (Fu et al., 2002; Smy'kal et al., 2011; Žiarovská et al., 2012; Habibollahi et al., 2015).

In order to maintain and exploit the genetic resources efficiently, an understanding of the amount and distribution of the genetic variation within and among accessions in a collection is required (Žiarovská et al., 2012). Molecular markers are highly useful both to identification of potentially novel genotypes among the many flax accessions and to the assessment of the genetic diversity for both germplasm management and core collection assembly (Smy'kal et al., 2011).

Different measures are used to quantify the distribution of genetic variation among individuals within populations, and among populations. These measures describe how genetic variation is partitioned within species. These include Wright's inbreeding coefficient (Fst) and Nei's coefficient of gene variation (Gst, Falk et al., 2001).

Values of Fst and Gst vary from 0 to 1 . GST in particular has a number of useful properties: it can be used for one or many loci, mutation rates do not alter the statistic significantly, the exact number of populations need not be specified, and the statistic is relatively responsive to changes in allele frequencies in time. Although they have important conceptual differences, in practice Fst and Gst are used in similar fashion as indices of the genetic difference among populations (Crow, 1986).

In species with low Gst (approaching 0), the majority of variation is found within populations; individuals within populations are likely to be genetically different, but each population contains the same complement of alleles in similar frequencies where Gst is high (approaching 1). Individuals within a population are relatively similar but populations are significantly different (Freeland et al., 2011).
In the present investigation we used both measures of genetic differentiation. They revealed a low value for both estimated pair-wise Fst and Gst between populations. These low values indicate either a high degree of gene flow among the studied populations or the presence of many common shared ancestral alleles in them (Sheidai et al., 2014, 2015).

The distribution of genetic variation within and among species is strongly linked to life-history traits, particularly to the dispersal and reproductive mode (Hamrick et al. 1991). Plant species that disperse their genes widely and frequently will tend, other things being equal, to have a lower Gst value (i.e., populations will be more similar). Linum is a predominantly selfing species therefore we cannot expect extensive open pollination and wide dispersal in this species. Moreover, the plants studied are cultivated in different cities with no chance for gene exchange.

K-Means clustering also showed the presence of one or two genetic groups and the STRUCTURE plot revealed very close genetic similarities between the studied species and populations due to the common shared alleles. Moreover, population assignment test revealed a high degree of inter-population genetic admixture. We therefore consider the ancestral conserved common alleles responsible for the high degree of genetic similarity observed in these species and populations. These results are in agreement with the study of Soto-Cerda et al. (2013), who investigated 407 flax accessions by using 448 microsatellite loci. These accessions were grouped in six major clusters, which showed weak general population differentiation $\left(\mathrm{F}_{\mathrm{ST}}=0.094\right)$ and weak pairwise population differentiation among sub-groups.

Therefore, the present study supported a close genetic affinity between $L$. usitatissimum and $\mathrm{Li}$ num bienne, and revealed the presence of similar genetic content in the populations of L. usitatissimum. This means that we need to broaden the genetic pool of this species in Iran if we want to obtain superior cultivars with suitable genetic content and agronomic traits. We should introduce some foreign cultivars into the country 
and perform genetic and phenotypic diversity analyses on them to select the most divergent cultivars for future hybridization and selection.

Received 10 October 2016

Accepted 19 January 2017

\section{References}

1. Afshar F, Sheidai M, Talebi SM, Keshavarzi M. Bayesian and Multivariate Analyses of combined molecular and morphological data in Linum austriacum (Linaceae) populations: evidence for infraspecific taxonomic groups. Biodiversitas. 2015; 16: 179-87.

2. Chatti K, Saddoud O, Salhi-Hannachi A, Marrakchi M, Trifi M, Mars M. RAMPO: a powerful molecular marker in fig (Ficuscarica) diversity analysis. ISHS Acta Horticulturae 798: III International Symposium on Fig. Vilamouran, Algarve, Portugal. 2008; DOI: 10.17660/ActaHortic.2008.798.25

3. Crow JF. Basic concepts in population, quantitative, and evolutionary genetics.New York: W. H. Freeman \& Co; 1986.

4. Falk DA, Knapp E, Guerrant EO. An introduction to restoration genetics. Washington, DC: Plant Conservation Alliance, Bureau of Land Management, US Environmental Protection Agency; 2001. p. 24.

5. Falush D, Stephens M, Pritchard JK. Inference of population structure using multilocus genotype data: dominant markers and null alleles. Mol Ecol Notes. 2007; 7: 574-8.

6. Freeland JR, Kirk H, Peterson SD.; Molecular Ecology. 2nd ed. UK: Wiley-Blackwell; 2011. p. 449.

7. Fu YB, Diederichsen A, Richards KW, Peterson G. Genetic diversity within a range of cultivars and landraces of flax (Linum usitatissimum L.) as revealed by RAPDs. Genet. Res. Crop Evol. 2002; 49: 167-74.

8. Govindaraj M, Vetriventhan M, Srinivasan M. Importance of genetic diversity assessment in crop plants and its recent advances: an over- view of its analytical perspectives. Genet Res Intern. 2015; 1-14.

9. Habibollahi H, Noormohammadi Z, Sheidai M, Farahani F. Genetic structure of cultivated flax (Linum usitatissimum L.) based on retrotransposon-based markers. Genetika. 2015; 47(3): 1111-22.

10. Habibollahi H, Noormohammadi Z, Sheidai M, Farahani Fю SSR and EST-SSR-based population genetic structure of Linum L. (Linaceae) species in Iran. Genet Resour Crop Evol. 2016; 63: 127-1138.

11. Hamer $Ø \mathrm{~m}$, Harper DAT, Ryan PD. PAST: Paleontological Statistics software package for education and data analysis. Palaeontol Electron. 2012; 4: 9.

12. Hamrick JL, Godt MJW, Murawski DA, Loveless MD. Correlations between species traits and allozyme diversity: implications for conservation biology. In: Falk DA, Holsinger KE, editors. Genetics and conservation of rare plants. New York: Oxford University Press; 1991.

13. Hedrick PW. A standardized genetic differentiation measure. Evolution. 2005; 59: $1633 \mathrm{e} 1638$.

14. Huson DH, Bryant D. Application of phylogenetic networks in evolutionary studies. Mol Bio Evol. 2006; 23: 254e267. The software is available from: www.splitstree.org.

15. Jost L. GST and its relatives do not measure differentiation. Mol Ecol. 2008; 17: 4015e4026.

16. Krizman M, Jakse J, Baricevic D, Javornik B, Mirko P. Robust CTAB-activated charcoal protocol for plant DNA extraction. Acta Agri Slov. 2006; 87: 427-33.

17. McDill J, Repplinger M, Simpson BB, Kadereit JW. The phylogeny of Linum and Linaceae subfamily Linoideae, with implications for their systematics, biogeography, and evolution of heterostyly. Syst Bot. 2009; 34(2): 386-405.

18. Meirmans PG. AMOVA-based clustering of population genetic data. J Hered. 2012; 103 : $744 \mathrm{e} 750$.

19. Peakall R, Smouse PE. GENALEX 6: genetic analysis in Excel. Population genetic software 
for teaching and research. Mol Ecol Notes. 2006; 6: 288-95.

20. Pritchard JK, Stephens M, Donnelly P. Inference of population structure using multilocus genotype data. Genetics. 2000; 155: 945-59.

21. Sheidai M, Afshar F, Keshavarzi M, Talebi SM, Noormohammadi Z, Shafaf T. Genetic diversity and genome size variability in Linum austriacum (Lineaceae) populations. Biochem Syst Ecol. 2014; 57: 20-6.

22. Sheidai M, Farahani F, Talebi SY, Noormohammadi Z. Genetic and morphological analysis of distyly in Linum mucronatum Bertol. Linaceae). Phytol Balcan. 2015; 21: 13-9.

23. Smy'kal P, Bačová-Kerteszová N, Kalendar R, Corander J, Schulman AH, Pavelek M. Genetic diversity of cultivated flax (Linum usitatissimum L.) germplasm assessed by retrotransposon-based markers. Theor Appl Genet. 2011; 122: 1385-97.

24. Soto-Cerda BJ, Diederichsen A, Ragupathy R, Sylvie Cloutier S. Genetic characterization of a core collection of flax (Linum usitatissimum L.) suitable for association mapping studies and evidence of divergent selection between fiber and linseed types. BMC Plant Biol. 2013; 13: 78.

25. Tamarzizt HB, Mustapha SB, Baraket G, Abdallah D, Salhi-Hannachi A. Assessment of genetic diversity and relationships among wild and cultivated Tunisian plums (Prunus spp.) using random amplified microsatellite polymorphism markers. Genet. Mol. Res. 2015; 14 : 1942-56.

26. Weising K, Nybom H, Wolff K, Kahl G. DNA Fingerprinting in Plants. Principles, Methods, and Applications. 2nd ed. Boca Rayton: CRC Press; 2005. 472 p.

27. Žiarovská J, Ražná K, Senková $S$, Štefúnová V, Bežo M. Variability of Linum usitatissimum L. based on molecular markers. ARPN J Agri Biol Sci. 2012; 7: 50-8.

\section{Zahra Noormohammadi, Mina Sakhaee, Masoud Sheidai, Seyed Mehdi Talebi}

\section{LINUM L. GENETINĖS İVAIROVĖS VERTINI- MAS PANAUDOJANT SPAR ŽYMEKLIUS}

\section{Santrauka}

Linai (Linum usitatissimum subsp.) yra svarbūs augalų pasèliai, auginami tiek dèl pluošto, tiek ir dèl sèklų aliejaus. Suvienodintos auginimo sąlygos ir atranka gali lemti genetinę eroziją ir sumažinti genetinį Linum veislių kintamumą, kuris savo ruožtu mažina pasèlių atsparumą ligoms ir jų sukèlëjams. Atlikome kelių populiacijų genetinès ịvairovès analizę, tarp jų Linum usitatissimum subsp. usitatissimum L. ir L. Bienne L., naudodami pavieniu pradmenu amplifikacijos reakcijos molekulinius žymenis, įskaitant RAPD, ISSR ir RAMPO. Visi trys molekuliniai žymenys atskleidè mažą tirtų pavyzdžiu genetinio kintamumo lygi, tačiau L. bienne pasižymėjo aukštesnio lygio genetiniu kintamumu. Klasterinè ir tinklo analizè rodo augalų iš skirtingų populiacijų tarpusavio maišymąsi, tačiau populiacijos nesiskyrè viena nuo kitos. Struktūros analizè ir $\mathrm{K}$ priemonès grupavimas taip pat patvirtino šias populiacijas kaip genetiškai homogeniškas. Šie rezultatai rodo naujų sẻmenų veislių poreikị igyvendinant hibridizacijos ir veislininkystès programas.

Raktažodžiai: genetinis kintamumas, K priemonès grupavimas, Linum, struktūros analizè, SPAR 